\title{
Implications of the Digital Divide for the Learning Process During the COVID-19 Crisis
}

\author{
Gila Cohen Zilka ${ }^{1}$, Idit Finkelstein ${ }^{2}$, Revital Cohen ${ }^{2} \&$ Ilan Daniels Rahimi ${ }^{2}$ \\ ${ }^{1}$ Bar-Ilan University; the Director of the Department for Teaching Social Science and Communication; Achva \\ Academic College, Israel \\ ${ }^{2}$ Ono Academic College \\ Correspondence: Gila Cohen Zilka, Bar-Ilan University; the Director of the Department for Teaching Social Science \\ and Communication; Achva Academic College, Israel
}

Received: March 14, 2021 Accepted: April 12, 2021 Online Published: April 25, 2021

doi:10.5539/res.v13n2p57 URL: https://doi.org/10.5539/res.v13n2p57

\begin{abstract}
With the outbreak of the COVID-19 crisis, higher education institutions organized for online learning. The aim of the present study was to examine the implications of online learning for students with limited access to information and communication technology (ICT), content infrastructures, and digital environments, assuming that such limited access may impair their ongoing learning process when instruction moves online, and cause situations of stress and frustration, as well as a desire to drop out of school. The mixed-method study involved 639 students studying at institutions of higher education in Israel, who completed a questionnaire containing open and closed questions. The findings show that $13 \%$ of participants reported that they had limited access, difficulties, and malfunctions resulting from a weak connection to the Internet, and numerous disconnects, especially during synchronous lectures. They reported having difficulties downloading content from the Internet and uploading materials. It has been shown that limited access to the Internet has implications for the learning process, motivation, self-efficacy, as well as for feelings and emotions. It is liable to lead to the widening or the creation of gaps between students who have full and those who have limited access to the Internet. The findings show that little use is made of forums $(10 \%)$. A more extensive use of the forums is recommended in courses where students have limited access to the Internet, to create a supportive learning community.
\end{abstract}

Keywords: information and communication technology (ICT), distance learning; equal opportunities, social emotional learning (SEL)

\section{Introduction}

With the outbreak of the COVID-19 crisis, higher education institutions organized for online learning (Agarwal \& Kaushik, 2020; Dhawan, 2020; Riva et al., 2020). The aim of the present study was to examine the implications of online learning for students with limited access to information and communication technology (ICT), content infrastructures, and digital environments, assuming that such limited access may impair their ongoing learning process when instruction moves online, and cause situations of stress and frustration, as well as a desire to drop out of school.

\subsection{The Purpose of Study}

In this study, we examined the correlation between limited/full accessibility, use of tools and skills, democratic principles in learning, students' motivation and self-efficacy, and feelings and emotions during the COVID-19 crisis. It is important to examine the learning experiences of students who have full and limited access to a digital environment because limited access is liable to lead to the widening or the creation of gaps between students who have a full access to the Internet and those who have limited access.

\section{Digital Learning Environments}

The digital environment changes a person's existential, social, and cultural environment. It brings about a change in individuals' behavior, lifestyle, the manner of communication with others, the extent to which they need and the way they locate and process information, and in their thinking patterns (Carr, 2011; Chen \& Su, 2019; Hayles, 2012; Lieberman, 2021; Rahayu, 2020; Zilka, 2016, 2019a). The digital environment has led to cancelling the boundaries of time and place. At present, learners have fascinating and varied opportunities for collaboration and learning, which are not limited in time or place (Feenberg, 2010; Mahler, 2012). Researchers (Cohen et al., 2015 Zilka et al., 2018) found that the digital environment leads to increased motivation of learners, increased academic and social engagement, and provides 
fascinating and diverse environments. It helps learners understand the study material through images, animations, simulations, and videos available to learners online. Researchers examined the integration of digital environments into the learning process (Jan et al., 2016; Johnson et al., 2011) and found that their availability "anywhere and anytime" makes it possible to make learning part of the learners' daily routine, and foster learner involvement and collaboration. It also allows creating equal opportunities for learners with special needs (Ardito et al., 2006; Gikas \& Grant, 2013). Researchers (Mayer, 2014; Zohar \& Levy, 2019) found that factors that determine the "user experience" stem from the capabilities and limitations of the sensory system and the basic processing of sensory information in the brain. Therefore, changes in font size, font color, background, and spacing can lead to a change in the students' learning process.

\subsection{Integrating Democratic Learning Principles}

Democratic principles in learning and teaching provide learners with challenging learning environments that encourage innovation and initiative, fostering personality traits, approaches, talents and generic skills (Cochran-Smith et al., 2018; Sahlberg, 2010; Scott, 2016). They also encourage the development of thinking skills in various fields, such as the ability to choose a suitable medium from the wide variety available, skills in using hardware, software, and digital communication tools for different needs (Ertmer \& Ottenbreit-Leftwich, 2010; Zilka, 2017a, 2017b, 2020a). The digital environment serves as an intellectual partner for learners in the construction, processing, and presentation of knowledge, in the activation of meta-cognitive reflective processes, processes of self-direction, and cognitive, emotional, and differential processes (Christensen et al., 2008; Voogt \& Pelgrum, 2005; Zilka, 2019). It serves in the development of social and emotional learning (SEL) skills; of self-awareness, social adaptability in a changing reality, collaborative skills, inclusion, self-acceptance and acceptance of the other, maintaining privacy; the development of emotional attitudes and skills, focusing on social, cross-cultural, and global skills; sharing and collaborations, personal and social development, development of self and social leadership, multiculturalism, and a protected environment (Bell, 2015; Brush \& Saye, 2014; De Pinho et al., 2015; Cochran-Smith et al., 2018; Sahlberg, 2010; Scott, 2016). It encourages the formation of an authentic personal identity rooted in firm values in a changing world. It develops the learners' responsibility and commitment to their learning. It promotes teacher-student dialogue and dialogue between students. It allows addressing differences between learners and provides for equal opportunities and reducing gaps between learners (Au, 2016; Cochran-Smith et al., 2018; Horizon Report, 2017; Zilka, 2019b).

Online learning processes. Online learning refers to a digital teaching system that connects students and teachers separated from each other by physical distance. An online environment allows students to intensify the learning process and usually provides a wide berth for inquiry-based learning, inclusion of texts (visual, auditory, and verbal), and the integration of higher-order thinking tasks. Because of the dynamism and variety of possibilities it offers, an online learning environment allows honing interpersonal communication skills, and supports collaboration and spatial division (Feenberg, 2010; Zilka, 2020b; Zilka et al., 2018; Zilka et al., 2019). At the same time, physical separation between teacher and students is liable to create transactional distance. This concept, coined by Moore (1993), indicates the presence of a psychological-communicative space between the teacher and the learners, which is liable to emerge in the learning process, causing negative feelings such as anger and leading to gaps in understanding or to learners' misconceptions about themselves and the learning process. According to Moore, the psychological-communicative space is not a permanent factor, but a variable that can be reduced.

\section{Motivation, Perception of Self-Efficacy, and Social-Emotional Aspects}

\subsection{Motivation}

Ford (1992) defined motivation as a psychological state that stimulates, directs, and preserves human behavior aiming at a particular goal. Motivation is an internal process that directs the person to perform an action and persevere in it (Law et al., 2010; Law \& Breznik, 2017; Law \& Geng, 2018; Reeves, 2006).

\subsection{Self-efficacy}

Researchers (Bandura, 1986; Schunk, 1989) defined self-efficacy as a persons' judgment regarding their ability to organize and successfully perform tasks and actions. The researchers argued that self-efficacy affects the choice of activities, effort, and perseverance of the learner. Individuals with a sense of self-efficacy invest more effort and persevere more than those who doubt their ability. Self-efficacy derives from previous experience, received feedback, and physiological arousal. If students feel capable of accomplishing the assignment, their sense of self-efficacy increases, and when they do not feel this way, their self-efficacy decreases (Bandura, 1995; Chamorro-Premuzic et al., 2010; Schneider $\&$ Preckel, 2017).

\subsection{Social-Emotional Learning (SEL) Aspects}

Researchers (Husaj, 2016; Maurice \& Harriett, 2006; Zilka, 2017b) noted that teaching based on this approach involves the advancement and application of social and emotional skills, in socially and culturally appropriate ways for students, 
based on the understanding that emotional and social difficulties affect the students' mental wellbeing, academic achievement, and general mood. Researchers separated the goals of the method into five interconnected arrays: self-awareness, self-management, social awareness, interaction management, and assuming responsibility (Beauchamp, 2015; Farr, 2010; Husaj, 2016; Liu, 2015; Maurice \& Harriett , 2006; Nooreiny, 2007; Zilka, 2017b).

\section{Digital Divide}

\subsection{Accessibility and Skills}

The digital divide is defined as the gap between those who have full access to digital environments, the Internet and computers, and those who have limited access or none at all, and as a gap between those who have digital literacy and those who have partial skills (Castells, 2009; Goyal, 2010; Hsieh et al., 2008; Meinrath et al., 2011; Mesch \& Talmud, 2011; Resta \& Laferrière, 2015; Ramsetty \& Adams, 2020; Zilka, 2016, 2017b, 2019a).

The indicators of digital gaps are expressed in the following aspects (Deursen \& Dijk, 2018; Hsieh et al., 2008; Sylvester et al., 2017; United Nations, 2020; Zilka, 2016, 2019a).

1. Access to ICT, content infrastructures, and digital environments: access to the Internet, computers, and other computerized devices, and fast access to information (Katz \& Rice, 2003; Livingstone \& Sefton-Green, 2016; Talukdar \& Gauri, 2011; Wareham et al., 2004; Zilka, 2016, 2019a). Digital environments imply environments that contain diverse sources of information and tools, that allow access to multi-representation of content (text, animation, sound, video, etc.); hypertext; visual means of illustration (through images, simulations, films that illustrate natural phenomena); and interactive functionality that assists the construction of knowledge in a friendly and entertaining way.

2. Digital literacy (OECD, 2018, 2019a, 2019b; Zilka, 2016, 2017a, 2019a), refers to the "21st century skills" required for use in digital environments, according to the OECD outline regarding the Life Long Learning (LLL) program - skills related to the need for information, to locating and identifying information, to dynamic reading and reading as a process, to identifying the main and the secondary points of an issue, and mapping concepts, ideas, and values in the text; to evaluating the information; to information processing and personal interpretation; to asking questions and analyzing claims, their justification, or rejection; to consolidating and expressing an opinion and taking a stand; to writing a text, processing and merging information from a variety of digital sources using diverse and advanced digital tools; to using collaborative tools, such as forums, shared files, blogs, and open content repositories; and to understanding the characteristics, benefits, and limitations of digital environments.

This study examined the implications of online learning for students with limited access to ICT, content infrastructures, and digital environments, assuming that such limited access may impair their ongoing learning process after it moves online, and causes situations of stress and frustration, as well as a desire to drop out of school.

Our research question was: What are the implications of limited access to ICT for the learning process, motivation, self-efficacy, and emotional and social aspects of students during the COVID-19 crisis? We examined the correlations between students' limited/full access, use of tools and skills, democratic principles in learning, and motivation and self-efficacy during the COVID-19 crisis.

\section{Methodology}

This was a mixed-method study (Civitillo et al., 2017). The questionnaire contained closed and open-ended questions.

We conducted discourse analysis on the findings obtained from the open-ended answers, based on the approach formulated by Adler and Adler (2008), Atkinson and Delamont (2006), and Hammersley (2008), to identify distinct elements and formulate contrasting, complementary, and explanatory themes, as described by Baskarada (2014), Braun and Clarke (2006), Pope and Mays (2009), Spencer et al., (2003), and Tracy (2019). We emphasized contextual discourse analysis of the complexity of learning in an online environment.

\section{Sample}

The study involved 639 participants. The average age of the participants was 33 years. Most respondents were women (about 78\%). Eighty-two (13.1\%) participants reported having limited access to ICT. Among those with limited access to ICT, the proportion of women was significantly higher (approximately 81\%) compared with those with full access (approximately 74\%). The vast majority of the sample reported that they had no learning disabilities (approximately $92 \%)$.

\section{Research Tool}

The questionnaire contained closed and open-ended questions. It was based on questionnaires used in previous studies: 
Digital Literacy questionnaire, Digital Gap Indicators questionnaire, Self-Efficiency questionnaire, Motivational questionnaire, and Challenges questionnaire (Bandura, 1986; Lazarus \& Folkman, 1988; Pintrich et al., 1991; Zilka, 2017a, 2017b, 2019a; Zilka, Rahimi, \& Cohen, 2019).

1. Demographic details included age, gender, learning disabilities, marital status, number of children.

2. Connection to the Internet. Type of Internet connection; Have you encountered any technical problems or other difficulties in using the technology in the last few weeks? If so, list the problems you had (such as Internet connection problems, disconnects, etc.).

3. Learning in online courses - tools, skills. Participants marked the range of digital tools and learning skills they have used in recent weeks, in the online courses they attended (tools and skills are detailed in Tables 1 and 2). Each tool and skill was coded as 1 (used) or 0 (not used). A comprehensive index of digital tools and the comprehensive index of learning skills were calculated based on the sum of values of the relevant statements in each category.

A digital tools index was calculated as the sum of 11 items. Cronbach alpha reliability for the current sample was $\alpha$ $=0.70$. The range of values was 0-11, a higher score indicating a higher level of use of the digital tools.

A learning skills index was calculated as the sum of 10 items. Cronbach alpha reliability for the current sample was $\alpha=0.77$. The range of values was $0-10$, a higher score indicating a higher level of use of learning skills.

4. SEL aspects, feelings of self-efficacy, challenge/threat, and motivation. Attitudes and feelings about the learning experience during the COVID-19 period. Students were asked to read 39 statements and score them on a 5-point Likert scale ranging from $1=$ Not at all, to $5=$ To a great extent. For example: I feel overwhelmed by online learning; I feel that online learning is at least as effective for me as face-to-face learning; I discovered that I had better learning habits than I thought; On online forums, I feel like I have something to learn from others; I feel it's a waste of time; Because of the change in the way of learning, I feel sad and despondent; Because of the change in the way of learning, I developed my ability to learn independently. We performed a principal component factor analysis with Varimax rotation on the questionnaire that included 39 statements. Analysis of confirmatory factors revealed three factors that together explain about $56 \%$ of the overall variance of the scale. Below is a breakdown of the results for the three factors and the results of preliminary reliability tests conducted to construct the questionnaire indices. Factor 1, Motivation for learning in an online environment (21 statements): Cronbach $\alpha=$ 0.95; Factor 2, Dealing with difficulties and problems (12 statements): Cronbach $\alpha=0.75$; Factor 3, Sense of self-efficacy (6 statements): Cronbach $\alpha=0.85$.

5. Democratic learning principles. The variable was measured using 8 questionnaire statements. The answers were scored on a 5-point Likert scale ranging from $1=$ Not at all, to $5=$ To a great extent. For example: students' commitment to the learning process; students' choice of assignments; development of students' reflective skills; development of students' social emotional skills; active inquiry-based learning (digital libraries / learning centers / information centers available to students); cooperation between students / thinking community / forums; encouraging dialogical exchange between students; differences between students are addressed. The variable was constructed as the mean of the answers, so the higher the value, the higher the level of democratic learning principles. Cronbach alpha for the current sample was $\alpha=0.91$.

6. Open questions. Significant learning experiences during the COVID-19 period, positive/negative elements in the online learning experience. What were the most significant learning experiences during the COVID-19 period?

\section{Findings}

Below we present the findings in the following order: access to digital tools and learning skills, attitudes and feelings about the learning experience during the COVID-19 period, democratic learning principles, SEL variable predictive model, correlations between key research variables, negative elements in the learning experience (quality discourse analysis).

\section{Access to the Internet, Use of Digital Tools, and Learning Skills}

Participants were asked to clarify their access to the Internet. The findings show that 269 (43\%) of all participants reported that they had full access to the Internet and that they did not encounter any Internet communication problems or problems downloading materials requested by the lecturers, movies, or software; 275 (44\%) participants reported having good, but not full and fast, access; they reported few problems, mainly in downloading materials from the Internet; $82(13.1 \%)$ participants reported having limited access, resulting in many difficulties and problems due to weak Internet, many interrupted connections, especially during synchronous lectures, difficulty or inability downloading materials from the Internet, and difficulty uploading materials to the Internet.

Participants were presented with a list of digital tools and learning skills, and were asked which ones they used in the 
online courses they took during the COVID-19 period.

Table 1 shows the distribution of the frequency of use of digital tools, both for the entire sample and according to access to technology (the table shows the percentages of participants who responded that they used tools).

Table 1. Prevalence of the use of digital tools in the entire sample and by access to technology $(\mathrm{N}=639)$

\begin{tabular}{|c|c|c|c|c|}
\hline & Entire sample & $\begin{array}{l}\text { Full access } \\
\qquad \mathrm{N}=267\end{array}$ & $\begin{array}{c}\text { Limited } \\
\text { access } \\
\mathrm{N}=356\end{array}$ & $\chi^{2}$ \\
\hline Digital tools & $N(\%)$ & $N(\%)$ & $N(\%)$ & \\
\hline Course website & $(\% 80.2) 506$ & (\%80.9) 216 & (\%75.9) 283 & 0.18 \\
\hline Real-time lectures & $(\% 88.3) 557$ & \%89.1) 238 & (\%87.9) 313 & 0.22 \\
\hline $\begin{array}{l}\text { Links to videos on the } \\
\text { Web }\end{array}$ & $(\% 50.4) 318$ & (\%55.1) 147 & $(\% 47.5) 169$ & 3.51 \\
\hline Exercise sheets & $(\% 23.8) 150$ & $(\% 25.8) 69$ & $(\% 22.2) 79$ & 1.12 \\
\hline Interactive environments & $(\% 20.0) 126$ & $(\% 22.5) 60$ & $(\% 18.5) 66$ & 1.46 \\
\hline $\begin{array}{lrl}\text { Digital libraries } & \text { / } \\
\text { learning } & \text { centers } \\
\text { information } & \text { centers }\end{array}$ & $(\% 21.9) 138$ & $(\% 18.7) 50$ & (\%23.9) 85 & 2.38 \\
\hline $\begin{array}{l}\text { Personal assignments on } \\
\text { the course website }\end{array}$ & $(\% 47.4) 303$ & (\%47.6) 127 & (\%48.9) 174 & 0.10 \\
\hline $\begin{array}{l}\text { Group assignments on } \\
\text { the course website }\end{array}$ & $(\% 20.8) 131$ & $(\% 17.6) 47$ & (\%23.3) 83 & 3.01 \\
\hline $\begin{array}{l}\text { Links to free online } \\
\text { databases }\end{array}$ & $(\% 9.4) 59$ & $(\% 11.2) 30$ & $(\% 8.1) 29$ & 1.69 \\
\hline $\begin{array}{l}\text { Use of advanced online } \\
\text { tools }\end{array}$ & $(\% 21.1) 133$ & (\%19.9) 53 & $(\% 22.2) 79$ & 0.50 \\
\hline Forums & $(\% 9.7) 62$ & $(\% 9.4) 25$ & \%10.4) 37 & 0.18 \\
\hline
\end{tabular}

$p<.05^{*}, p<.01^{* *}$

Table 2 shows the distribution of the frequency of use of learning skills, both for the entire sample and by access to technology (the table shows the percentage of participants who responded that they did use the learning skills). 
Table 2. Prevalence of the use of learning skills in the entire sample and by access to technology $(N=639)$

\begin{tabular}{lcccc}
\hline & Entire sample & Full access & $\begin{array}{c}\text { Limited } \\
\text { access } \\
\mathrm{N}=356\end{array}$ & $\chi^{2}$ \\
\hline Learning skills & $N(\%)$ & $N(\%)$ & $N(\%)$ & \\
\hline $\begin{array}{l}\text { Locating } \\
\text { information }\end{array}$ & $(\% 22.5) 142$ & $(\% 22.7) 60$ & $(\% 22.6) 80$ & 0.97 \\
$\begin{array}{l}\text { Processing } \\
\text { information }\end{array}$ & $(\% 11.1) 70$ & $(\% 8.2) 22$ & $(\% 13.2) 47$ & $3.81 *$ \\
$\begin{array}{l}\text { Merging texts } \\
\begin{array}{l}\text { Dynamic reading } \\
\text { and process reading }\end{array}\end{array}$ & $(\% 9.2) 58$ & $(\% 8.6) 23$ & $(\% 9.6) 34$ & 0.16 \\
$\begin{array}{l}\text { Asking questions } \\
(\% 11.6) 73\end{array}$ & $(\% 9.7) 26$ & $(\% 12.9) 46$ & 1.51 \\
$\begin{array}{l}\text { Analyzing claims } \\
\text { Expressing } \\
\text { opinions/positions }\end{array}$ & $(\% 13.6) 86$ & $(\% 15.0) 40$ & $(\% 12.9) 46$ & 0.54 \\
$\begin{array}{l}\text { Combining } \\
\text { information }\end{array}$ & $(\% 26.1) 165$ & $(\% 29.6) 79$ & $(\% 24.2) 86$ & 2.31 \\
$\begin{array}{l}\text { Mapping concepts } \\
\text { in a digital text }\end{array}$ & $(\% 7.8) 49$ & $(\% 29.2) 104$ & 2.84 \\
$\begin{array}{l}\text { Peer learning } \\
(\% 22.3) 141\end{array}$ & $(\% 24.7) 66$ & $(\% 21.1) 75$ & 1.16 \\
\hline
\end{tabular}

Table 2 shows that the most common learning skills used were: asking questions (about 31\%), expressing an opinion and taking a stand (about 25\%); locating and collecting information (about 22\%); and peer learning (about 22\%). Next, among less frequently used skills were analysis of claims presented in the text, their justification or rejection (about 13\%); dynamic and process reading, with identification of the essential and secondary content and marking of concepts/ideas/values in the text (about 12\%); processing information from verbal, visual, and vocal information sources and turning it into knowledge (about 11\%); merging information from a variety of digital texts (about 10\%); skills for merging texts (about 9\%); and conceptual mapping of digital text (about 7\%).

Significant differences were found between students with full and partial access to technology in the frequency of the use of information processing and its transformation into knowledge. Students with partial access to technology used it at a higher rate (13\%) than did those with full access. For the rest of the learning skills, no differences were found in the frequency of use between those with full access to technology and those with partial access.

\section{Attitudes and Feelings About the Learning Experience During the COVID-19 Period}

Table 3 shows the distribution of averages and standard deviations of the questionnaire variables. In addition, a t-test was performed for independent samples to examine the differences in these variables according to access to technology. 
Table 3. Mean distribution of attitudes and feelings about the learning experience in the COVID-19 period for the entire sample and by access to technology

\begin{tabular}{|c|c|c|c|c|c|c|c|c|}
\hline \multirow{2}{*}{ Self-efficacy } & & \multicolumn{2}{|c|}{$\begin{array}{l}\text { Entire sample } \\
\qquad \begin{array}{c}\mathrm{N}=639 \\
\mathrm{M}(\mathrm{SD})\end{array}\end{array}$} & \multicolumn{2}{|c|}{$\begin{array}{l}\text { Full access } \\
\qquad \begin{array}{l}\mathrm{N}=267 \\
\mathrm{M}(\mathrm{SD})\end{array}\end{array}$} & \multicolumn{2}{|c|}{$\begin{array}{c}\text { Limited access } \\
\quad \mathrm{N}=356 \\
\mathrm{M}(\mathrm{SD})\end{array}$} & $\mathrm{t}$ \\
\hline & & $(0.96)$ & 3.17 & $(0.90)$ & 3.39 & $(0.95)$ & 3.03 & $4.66^{* *}$ \\
\hline $\begin{array}{l}\text { Coping } \\
\text { difficulties } \\
\text { problems }\end{array}$ & $\begin{array}{l}\text { with } \\
\text { and }\end{array}$ & $(0.67)$ & 3.44 & $(0.63)$ & 3.57 & $(0.66)$ & 3.37 & $3.64 * *$ \\
\hline $\begin{array}{l}\text { Motivation } \\
\text { learning }\end{array}$ & for & $(0.81)$ & 3.45 & $(0.76)$ & 3.65 & $(0.80)$ & 3.32 & $5.09 * *$ \\
\hline
\end{tabular}

$p<.05^{*}, p<.01^{* *}$

Significant differences were found in the level of self-efficacy $(\mathrm{t}(594)=4.66, \mathrm{p}<.01)$, coping with difficulties $(\mathrm{t}(595)=$ $3.64, \mathrm{p}<.01)$ and motivation for learning $(\mathrm{t}(594)=5.09, \mathrm{p}<.01)$ by access to technology. The level of self-efficacy, coping with difficulties and problems, and the motivation to learn of students with full access to technology were significantly higher than those of students with limited access to technology.

\section{Democratic Learning Principles}

Table 4 shows the distribution of averages and standard deviations of the democratic learning principles variable. We performed a t-test for independent samples to examine the differences according to access to technology.

Table 4. Distribution of averages of democratic learning principles for the entire sample by access to technology

\begin{tabular}{|c|c|c|c|}
\hline \multirow[t]{2}{*}{ Entire sample } & Full access & \multicolumn{2}{|c|}{ Limited access } \\
\hline & & $\mathrm{N}=356$ & $\mathrm{t}$ \\
\hline $\mathrm{N}=639$ & $\mathrm{~N}=267$ & $M(S D)$ & \\
\hline $\mathrm{M}(\mathrm{SD})$ & $\mathrm{M}(\mathrm{SD})$ & & \\
\hline
\end{tabular}

Democratic

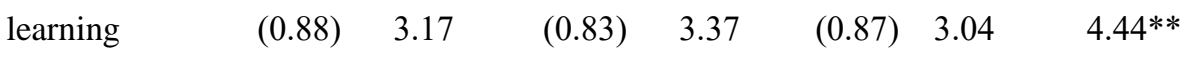

principles

$p<.05^{*}, p<.01 * *$

Table 4 shows that the level of democratic learning principles was moderate on average. Significant differences were found in democratic learning principles by access to technology $(\mathrm{t}(556)=4.44, \mathrm{p}<.01)$. Students with full access to technology reported significantly higher levels of democratic learning principles than did those with limited access to technology.

\section{Predictive Model}

To predict SEL variables (the emotional-social aspect of attitudes and feelings about the learning experience during the COVID-19 period), we performed a hierarchical linear regression model. In the first step, we introduced the socio-demographic control variable, and in the second step, the predictor of access to technology. The findings are presented in Table 5. 
Table 5. Hierarchical linear regression coefficients for predicting attitudes and feelings about the COVID-19 period learning experience

\begin{tabular}{|c|c|c|c|}
\hline & Self-efficacy & $\begin{array}{l}\text { Motivation to } \\
\text { learning }\end{array}$ & $\begin{array}{c}\text { Coping with } \\
\text { difficulties and } \\
\text { problems }\end{array}$ \\
\hline Predictors & $\beta$ & $\beta$ & $\beta$ \\
\hline \multicolumn{4}{|l|}{ First step } \\
\hline Marital status $(1=$ single $)$ & 0.01 & -0.05 & -0.01 \\
\hline Children (1=yes) & 0.08 & 0.02 & 0.09 \\
\hline Age & 0.07 & 0.07 & 0.01 \\
\hline Gender (1=male) & 0.03 & -0.03 & 0.04 \\
\hline \multirow{3}{*}{$\begin{array}{l}\text { Step two } \\
\text { Access to technology (1=full) }\end{array}$} & & & \\
\hline & $0.19 * *$ & $0.22 * *$ & $0.14^{* *}$ \\
\hline & $R^{2}=0.05$ & $R^{2}=0.06$ & $R^{2}=0.03$ \\
\hline
\end{tabular}

$p<.05^{*}, \overline{p<.01 * *}$

The regression for predicting self-efficacy was found to be significant $(\mathrm{F}(5,579)=6.44$, $\mathrm{p}<.01)$, with the predictive variables adding $5 \%$ to the explained variance of self-efficacy. We found that in the first step, the background variables did not make a significant unique contribution to the model. In the second step, the accessibility of technology variable made a distinct unique positive contribution to the model, so that full access to technology was associated with higher self-efficacy, and it added 5\% to the explained variance of self-efficacy.

The regression for predicting motivation to learn was found to be significant $(F(5,580)=8.06, p<.01)$, with the predictive variables adding $6 \%$ to the explained variance of motivation for learning. We found that in the first step the background variables did not make a significant unique contribution to the model. In the second step, the accessibility of technology variable made a distinct unique positive contribution to the model, so that full access to technology was associated with higher motivation for learning, and it added $6 \%$ to the explained variance of motivation for learning.

The regression for predicting coping with difficulties and problems was found to be significant $(\mathrm{F}(5,580)=3.65$, $\mathrm{p}<.01)$, with the predictive variables adding $3 \%$ to the explained variance of coping with difficulties and problems. We found that in the first step, the background variables did not make a significant unique contribution to the model. In the second step, the accessibility of technology variable made a significant unique positive contribution to the model, so that full access to technology was associated with better coping with difficulties and problems, and it added $3 \%$ to the explained variance of coping with difficulties and problems.

\section{The Correlations Between the Main Research Variables}

To examine the correlations between the main research variables, we performed a Spearman correlation. The findings are presented in Table 6. 
Table 6. Spearman correlations between the main research variables $(\mathrm{N}=631)$

\begin{tabular}{|c|c|c|c|c|c|c|}
\hline & 1 & 2 & 3 & 4 & 5 & 6 \\
\hline 1. Use of digital tools & --- & & & & & \\
\hline 2. Use of learning skills & $.54 * *$ & --- & & & & \\
\hline $\begin{array}{l}\text { 3. Democratic learning } \\
\text { principles }\end{array}$ & $.24 * *$ & $.22 * *$ & --- & & & \\
\hline 4. Self-efficacy & $.20 * *$ & $.14 * *$ & $.53 * *$ & --- & & \\
\hline $\begin{array}{l}\text { 5. Coping with difficulties and } \\
\text { problems }\end{array}$ & $.17 * *$ & .07 & $.20 * *$ & $.45 * *$ & --- & \\
\hline 6. Motivation to learn & $.23 * *$ & $.20 * *$ & $.54 * *$ & $.76 * *$ & $.26 * *$ & --- \\
\hline
\end{tabular}

$p<.05 *, p<.01 * *$

Table 6 shows that significant positive correlations were found between the use of digital tools and the use of learning skills ( $r s=0.54, p<.01)$, democratic learning principles ( $r s=0.24, p<.01)$, self-efficacy $(r s=0.20, p<.01)$, coping with difficulties and problems ( $r s=0.17, \mathrm{p}<.01$ ), and motivation for learning ( $\mathrm{rs}=0.23, \mathrm{p}<.01$ ). A higher level of use of digital tools was associated with a higher level of use of learning skills, democratic learning principles, self-efficacy, coping with difficulties and problems, and motivation for learning.

Significant positive correlations were found between the use of learning skills and democratic learning principles (rs $=$ $0.22, \mathrm{p}<.01$ ), self-efficacy ( $\mathrm{rs}=0.14, \mathrm{p}<.01$ ) and motivation for learning $(\mathrm{rs}=0.20, \mathrm{p}<.01)$. A higher level of use of learning skills was associated with a higher level of democratic learning principles, self-efficacy, and motivation for learning.

Significant positive correlations were found between democratic learning principles and self-efficacy $(r s=0.53, \mathrm{p}<.01)$, coping with difficulties and problems $(r s=0.20, \mathrm{p}<.01)$, and learning motivation $(\mathrm{rs}=0.54, \mathrm{p}<.01)$. A higher level of democratic learning principles was associated with a higher level of self-efficacy, coping with difficulties and problems, and motivation for learning.

Significant positive associations were found between self-efficacy and coping with difficulties and problems ( $\mathrm{rs}=0.45$, $\mathrm{p}$ $<.01$ ), and motivation for learning ( $r s=0.76, \mathrm{p}<.01)$. A higher level of self-efficacy was associated with a higher level of coping with difficulties and problems and motivation for learning. A significant positive correlation was also found between coping with difficulties and problems and motivation for learning $(r s=0.26, p<.01)$. A higher level of coping with difficulties and problems was associated with a higher level of motivation for learning.

\section{Negative Elements of the Learning Experience: Analysis of Answers by Students With Limited Internet Access}

Below is a selection of answers to the open question.

Load. Tension. Frustration. Helplessness. Many disconnects. Interruptions of the lecture sequence due to technical problems. It takes a lot of mental effort to listen to online lectures when there are technical problems. It's hard to concentrate. Unable to understand instructions and guidelines. Difficulty dealing with technology. Inability to download videos recommended by the lecturer from the Internet. Difficulty accessing certain links. A feeling that they are failing to learn and that their learning process has been impaired. Desire to stop or suspend studies.

\section{Discussion}

With the outbreak of the COVID-19 crisis, institutions of higher education organized for online teaching. The aim of the study was to examine the implications of online learning for students with limited access to ICT, content infrastructures, and digital environments, assuming that such limited access may impair their ongoing learning process after instruction moves online, and cause situations of stress and frustration, as well as a desire to drop out of school.

In this study, we examined the correlations between limited/full Internet accessibility, use of tools and skills, democratic principles in learning, motivation, and self-efficacy of students during the COVID-19 crisis.

\section{Digital Divide: Access to Digital Tools and Learning Skills}

The findings show that $82(13 \%)$ of the participants reported that they had limited access to the Internet, experienced 
many difficulties/failures because of a weak connection, many disconnects, especially during synchronous lectures, difficulty or inability to download materials from the Internet, and difficulty uploading materials to the Internet.

The findings (Table 1) show that the most commonly used digital tool was the Zoom video conferencing software to deliver real-time lectures. Students with limited access had many disconnects during the lectures, screen freezes, speaker sound problems and more, and they had to watch the recorded lectures in addition to the real-time lectures, which increased their load. In addition, it should be remembered synchronous lectures have different characteristics than face-to-face lectures. Researchers (Riva at al., 2020; Wiederhold, 2020) have noted that synchronous lessons delivered through applications such as Zoom have different characteristics from those of face-to-face lessons, and emphasized that in a synchronous lesson, orientation in a two-dimensional space differs from orientation in a face-to-face lesson. There is difficulty in locating the source of sound, locating and understanding the facial expressions of the person speaking, understanding interpersonal interactions, making eye contact, understanding messages, and in general, there is difficulty in the perception by individuals of their space. Therefore, many students complained about fatigue, concentration problems, feelings of overload and of blurring of boundaries, in other words, Zoom fatigue. It is recommended that in courses where students have limited access to the Internet, forums should be used to create a learning community and to bridge the psychological-communicative distance. The findings of the present study show that little use is made of forums (Table 1, about 10\%). Other researchers (Aboagye et al., 2020; Kapasia at al., 2020) found that during the COVID-19 crisis, forums were not widely used to bridge the psychological gap created by online learning. Garrison (2007) and Zilka et al. (2018) noted that teacher presence in a face-to-face lecture has different characteristics from that in an online lecture. They defined "lecturer presence" as meaningful communication for shaping, assisting, and directing cognitive and social processes, encouraging a participatory climate, encouraging community cohesion, and creating social presence. Researchers (Allen \& Seaman, 2010; Engstrom et al., 2008; Pittman \& Richmond, 2008; Zilka et al., 2018) defined "social presence" as creating a space for collaborative discourse, where students feel free to express their views and needs. Social presence is likely to reduce the psychological-communicative gap created by online learning between students, as a result of the students' lack of understanding or misconceptions about themselves and about the learning process, and create instead a sense of closeness, as opposed to isolation, a sense of safe haven, as opposed to that of anonymity (Edwards et al., 2011; Holley \& Dobson, 2008). Researchers (DeGennaro, 2008; Gomez et al., 2010; Velasquez et al., 2013) found that in online learning environments there was more extensive communication than in a face-to-face environment, that the forums allowed dialogue and created a space for distributed cognition - interactions between lecturers and students in a significant and branching out learning process. Integrating forums into distance learning enables the application of skills such as analysis of claims presented in the text, their justification or rejection, expressing opinions and taking a stand in forums. The findings (Table 2) indicate that skills such as expressing an opinion and taking a position (approximately 25\%), analyzing claims presented in the text, justifying them or rejecting them (approximately $13 \%$ ), were only partially present. Active participation in forums was usually possible even when there was only partial access to the Internet.

\section{Democratic Learning Principles}

Implementation of democratic principles in learning creates a challenging learning environment that encourages learners' innovation and initiative, cultivates personal characteristics, helps acquire methods, skills, and abilities. In this study, we examined whether democratic principles were reflected in learning, and we found that limited access to the Internet disrupted the learning process. The findings (Table 4) show that students with full access to technology reported significantly more expressions of democratic learning principles than did those with limited access to technology (13\%), who reported that these principles were expressed only in a limited way. The digital environment has led to the cancelling of the boundaries of time and place, and for some students served as a partner in the construction of knowledge, in the processing and presentation of knowledge, and in the activation of meta-cognitive reflective processes, self-direction processes, cognitive processes, and emotional and differential processes ( Voogt \& Pelgrum, 2005;Christensen et al., 2008; Zilka, 2020a).

\section{Attitudes and Feelings Regarding the Learning Experience During the COVID-19 Period}

An intriguing finding that emerged from this study is the correlation between limited Internet access and self-efficacy, coping with difficulties and problems, and motivation. The findings (Table 3) show that the levels of self-efficacy, coping with difficulties and problems, and motivation to learn of students with full access to technology are significantly higher than those of students with limited access to technology. It appears that full access to technology is associated with higher self-efficacy, higher motivation for learning, and better coping with difficulties and problems (Table 5). Motivation is an internal process that directs the person to perform an action and persevere in it (Law et al., 2010; Law \& Breznik, 2017; Law \& Geng, 2018; Reeves, 2006). When people must learn in an environment that imposes difficulties, motivation is impeded, as is their sense of self-efficacy and ability to successfully perform tasks and actions. If the students feel that they can accomplish the task, their self-efficacy increases, and if they do not feel like it, their self-efficacy decreases 
(Bandura et al., 1995; Chamorro-Premuzic et al., 2010; Schneider \& Preckel, 2017).

The findings of this study suggest that full access to technology is also associated with better coping with difficulties and problems, whereas a lack of full access is liable to impair the students' sense of resilience, ability to make decisions, self-management, and management of interactions. Researchers (Husaj, 2016; Zilka, 2017b) have argued that emotional and social difficulties affect learners' emotional wellbeing, academic achievement, and overall mood. Students related that they considered suspending or abandoning their studies, that it was difficult for them to learn because of the many disconnects and other difficulties. Below are some sample quotes from the responses of students with limited Internet access: "Online learning depends on the quality of Internet connection; I felt it on my hide. Before COVID-19, I used computers on campus. It's really hard for me now. I'm considering suspending my studies for a while." "Because of Zoom disconnects, I could not understand what was happening in the lessons, and then a gap was created in my knowledge, which made it difficult for me late." "The lecturer referred to videos, and I couldn't download them, so I couldn't complete the assignments on time." The analysis of the discourse on the negative elements in the learning experience of students who have limited access to the Internet shows that they felt overwhelmed by tension, frustration, and helplessness, in short, a sense that they were failing to learn and that their learning process has been impaired. This often led to a desire to stop or suspend their studies.

In conclusion, limited access to the Internet has implications for the learning process, for motivation, self-efficacy, and feelings and emotions, and it is liable to lead to the opening or widening of gaps between students who have full access and those who have limited access. It is recommended to incorporate additional digital tools for video conferencing. It is recommended that in courses where students have limited access to the Internet, forums be used to create a learning community to bridge the psychological-communicative distance. The use of a variety of digital tools may result in all students being able to apply democratic principles in learning, and in the digital environment becoming a partner in the construction of knowledge, the processing and presentation of knowledge, and the activation of meta-cognitive reflective processes, self-direction processes, as well as cognitive, emotional, and differential processes.

\section{Compliance with Ethical Standards}

Informed consent was obtained from all individual participants included in the study.

The study received approval from the institutional review board (IRB) of Achva Academic College.

No funding/grant for this study.

No conflict of interest.

\section{References}

Aboagye, E., Yawson, J. A., \& Appiah, K. N. (2020). COVID-19 and E-Learning: the Challenges of Students in Tertiary Institutions. Social Education Research, 109-115. https://doi.org/10.37256/ser.122020422

Adler, P. A., \& Adler, P. (2008). Of Rhetoric and Representation: The Four Faces of Ethnography. The Quarterly Sociological, 49(1), 1-30. https://doi.org/10.1111/j.1533-8525.2007.00104.x

Agarwal, S., \& Kaushik, J. S. (2020). Student's perception of online learning during COVID pandemic. The Indian Journal of Pediatrics, 87(7), 554. https://doi.org/10.1007/s12098-020-03327-7

Allen, I. E., \& Seaman, J. (2010). Learning on demand: Online education in the United States, 2009. The Sloan Consortium. Retrieved December 2020 from: https://eric.ed.gov/?id=ED529931

Ardito, C., Costabile, M. F., Marsico, M. D., Lanzilotti, R., Levialdi, S., Roselli, T., \& Rossano, V. (2006). An approach to usability evaluation of e-learning applications. Universal access in the information society, 4(3), 270-283. https://doi.org/10.1007/s10209-005-0008-6

Atkinson, E., \& Delamont, S. (2006). In the roiling smoke: qualitative inquiry and contested fields. International Journal of Qualitative Studies in Education, 19(6), 747-755. https://doi.org/10.1080/09518390600975974

$\mathrm{Au}, \mathrm{W}$. (2016). Meritocracy 2.0: High-stakes, standardized testing as a racial project of neoliberal multiculturalism. Educational Policy, 30(1), 39-62. https://doi.org/10.1177/0895904815614916

Bandura, A. (1986). Social foundations of thought and action: A social cognitive theory. Englewood Cliffs, NJ: Prentice-Hall.

Bandura, A. (1995). Self-efficacy in changing societies. New York: Cambridge University Press. https://doi.org/10.1017/CBO9780511527692

Baskarada, S. (2014). Qualitative case study guidelines. The Qualitative Report, 19, 1-18. 
https://doi.org/10.46743/2160-3715/2014.1008

Beauchamp, C. (2015). Reflection in teacher education: issues emerging from a review of current literature. $\begin{array}{lllll}\text { International and } \quad \text { Multidisciplinary } & \text { Perspectives, } & 16(1), & 123-141 .\end{array}$ https://doi-org.ezprimo1.idc.ac.il/10.1080/14623943.2014.982525

Bell, S. (2015). Project-Based Learning for the 21st Century: Skills for the Future, The Clearing House: A Journal of $\begin{array}{lllll}\text { Educational Strategies, } & \text { Issues }\end{array}$ https://doi-org.ezprimo1.idc.ac.il/10.1080/00098650903505415

Brush, T., \& Saye, J. (2014). Guest Editors' Introduction: Special Issue on Technology-Supported Problem-based Learning in Teacher Education. Interdisciplinary Journal of Problem-Based Learning, 8(1). https://doi.org/10.7771/1541-5015.1480

Carr, N. G. (2011). The shallows: What the internet is doing to our brains. New York, NY: W. W. Norton.

Castells, M. (2009). Communication power. New York, NY: Oxford University Press.

Chamorro-Premuzic, T., Harlaar, N., Greven, C. U., \& Plomin, R. (2010). More than just IQ: A longitudinal examination of self-perceived abilities as predictors of academic performance in a large sample of UK twins. Intelligence (38), 385-392. https://doi.org/10.1016/j.intell.2010.05.002

Chen, C. H., \& Su, C. Y. (2019). Using the BookRoll E-Book System to Promote Self-Regulated Learning, Self-Efficacy and Academic Achievement for University Students. Educational Technology \& Society, 22(4), $33-46$.

Christensen, C., Horn, M. B., \& Johnson, C. W. (2008). Disruptive class: How disruptive innovation will change the way the world learns. New York: McGraw Hill.

Civitillo, S., Schachner, M., Juang, L., van de Vijver, F. J., Handrick, A., \& Noack, P. (2017). Towards a better understanding of cultural diversity approaches at school: A multi-informant and mixed-methods study. Learning, Culture and Social Interaction, 12, 1-14. https://doi.org/10.1016/j.lcsi.2016.09.002

Cochran-Smith, M., Carney, M. C., Keefe, E. S., Burton, S., Chang, W. C., Fernandez, M. B., ... \& Baker, M. (2018). Reclaiming accountability in teacher education. Teachers College Press.

Cohen, J., Vincent, J. L., Adhikari, N. K., Machado, F. R., Angus, D. C., Calandra, T., \& Tracey, K. (2015). Sepsis: a roadmap for future research. The Lancet infectious diseases, 15(5), 581-614. https://doi.org/10.1016/S1473-3099(15)70112-X

De Pinho, L., Mota, F., Conde, M., Alves, L., \& Lopes, R. (2015) Mapping Knowledge Produced on Problem-Based Learning between 1945 and 2014: A Bibliometric Analysis. Creative Education, 6, 576-584. https://doi.org/10.4236/ce.2015.66057

DeGennaro, D. (2008). Learning designs: An analysis of youth-initiated technology use. Journal of Research on Technology in Education, 4l(1), 1-20. https://doi.org/10.1080/15391523.2008.10782520

Deursen, A. J. M. V., \& Dijk, J. A. V. (2018). The first-level digital divide shifts from inequalities in physical access to inequalities in material access. New Media \& Society, 7. https://doi.org/10.1177/1461444818797082

Dhawan, S. (2020). Online learning: A panacea in the time of COVID-19 crisis. Journal of Educational Technology Systems, 49(1), 5-22. https://doi.org/10.1177\%2F0047239520934018

Edwards, M., Perry, B., \& Janzen, K. (2011). The making of an exemplary online educator. Distance Education, 1(32), 101118. https://doi.org/10.1080/01587919.2011.565499

Engstrom, M., Santo, S., \& Yost, R. (2008). Knowledge building in an online cohort. The Quarterly Review of Distance Education, 9(2), 151-167.

Ertmer, P. A., \& Ottenbreit-Leftwich, A. T. (2010). Teacher technology change: How knowledge, confidence, beliefs, and culture intersect. Journal of Research on Technology in Education, 42(3), 255-284. https://doi-org.ezprimo1.idc.ac.il/10.1080/15391523.2010.10782551

Farr, F. (2010). The discourse of teaching practice feedback: A corpus-based investigation of spoken and written modes. London: Routledge. https://doi.org/10.4324/9780203846742

Feenberg, A. (2010). Btween reason and experience: Essays in technology and modernity. Cambridge. MA: Cambridge MIT Press. https://doi.org/10.7551/mitpress/8221.001.0001

Ford, M. E. (1992). Human motivation: Goals, emotions, and personal agency beliefs. CA: Sage: Newbury Park. 
https://doi.org/10.4135/9781483325361

Garrison, D. R. (2007). Online community of inquiry review: Social, cognitive, and teaching presence issues. Online Community of Inquiry Review. https://doi.org/10.24059/olj.v11i1.1737

Gikas, J., \& Grant, M. M. (2013). Mobile computing devices in higher education: Student perspectives on learning with cellphones, smartphones and social media. The Internet and Higher Education, 19, 18-26. https://doi.org/10.1016/j.iheduc.2013.06.002

Gomez, M. L., Schieble, M., Curwood, J., \& Hassett, D. (2010). Technology, learning and instruction: Distributed cognition in the secondary English classroom. Literacy, 44(1), 20-27. https://doi.org/10.1111/j.1741-4369.2010.00541.x

Goyal, A. (2010). Information, direct access to farmers, and rural market performance in central India. American Economic Journal: Applied Economics, 2(3), 22-45. https://doi.org/10.1596/1813-9450-5315

Hammersley, M. (2008). Questioning Qualitative Research: Critical Essays. London, UK: Sage. https://doi.org/10.4135/9780857024565

Hayles, K. (2012). How we think: Digital media and contemporary technogenesis. Chicago, IL: The University of Chicago Press. https://doi.org/10.7208/chicago/9780226321370.001.0001

Holley, D., \& Dobson, C. (2008). Encouraging student engagement in a blended learning environment: The use of contemporary learning spaces. Learning, Media, \& Technology, 33(2), 139-150. https://doi.org/10.1080/17439880802097683

Horizon Report, (2017). EDUCAUSE Learning Initiative (ELI) New Media Consortium (NMC). https://library.educause.edu/resources/2017/2/2017-horizon-report

Husaj, S. (2016). Social Emotional Learning (SEL). European Journal of Multidisciplinary Studies, 1(3), 168-171. http://dx.doi.org/10.26417/ejms.v1i3.p168-171

Hsieh, J. J., Rai, A., \& Keil, M. (2008). Understanding digital inequality: Comparing continued use behavioral models of the social-economically advantaged and disadvantaged. MIS Quart., 32, 97-126. https://doi.org/10.2307/25148830

Jan, S. R., Ullah, F., Ali, H., \& Khan, F. (2016). Enhanced and Effective Learning through Mobile Learning: An Insight into Students Perception of Mobile Learning at University Level. International Journal of Scientific Research in Science, Engineering and Technology, 2(2), 674-681.

Johnson, L., Smith, R., Willis, H., Levine, A., \& Haywood, K. (2011). The 2011 Horizon Report. Austin, TX: The New Media Consortium.

Kapasia, N., Paul, P., Roy, A., Saha, J., Zaveri, A., Mallick, R., Barman, B., Das, P., \& Chouhan, P. (2020). Impact of lockdown on learning status of undergraduate and postgraduate students during COVID-19 pandemic in West Bengal, India. Children and Youth Services Review, 105194. https://doi.org/10.1016/j.childyouth.2020.105194

Katz, J. E., \& Rice, R. E. (2003). Comparing internet and mobile phone usage: digital divides of usage, adoption, and dropouts. Telecommunications Policy, 27(8-9), 597-623. https://doi.org/10.1016/S0308-5961(03)00068-5

Lazarus, R. S., \& Folkman, S. (1988). Stress, appraisal and coping. New York: Springer.

Law, K. M. Y., Lee, V. C. S., \& Yu, Y. T. (2010). Learning motivation in e-learning facilitated computer programming courses. Computers \& Education, 55(1), 218-228. https://doi.org/10.1016/j.compedu.2010.01.007

Law, K. M. Y., \& Breznik, K. (2017). Impacts of innovativeness and attitude on entrepreneurial intention: Among engineering and non-engineering students. International Journal of Technology and Design Education, 27, 1-18. https://doi-org.ezprimo1.idc.ac.il/10.1007/s10798-016-9373-0

Law, K. M. Y., \& Geng, S. (2018). How innovativeness and handedness affect learning performance of engineering students? International Journal of Technology and Design Education, (3), 1-18. https://doi-org.ezprimo1.idc.ac.i1/10.1007/s10798-018-9462-3

Lieberman, M. (2021). Digital Games: Powerful Motivation Tool or Not So Much?. EducationWeek. https://www.edweek.org/technology/digital-games-powerful-motivation-tool-or-not-so-much/2021/01

Liu, K. (2015). Critical reflection as a framework for transformative learning in teacher education. Educational Review, 67(2),135-157. https://doi-org.ezprimo1.idc.ac.il/10.1080/00131911.2013.839546

Livingstone, S., \& Sefton-Green, J. (2016). The class: Living and learning in the digital age. New York, NY: New York University Press. https://doi.org/10.18574/nyu/9781479884575.001.0001 
Mahler, D. (2012). Teaching literacy in primary schools using an interactive whole-class technology: Facilitating student-to student whole-class dialogic interaction. Technology, Pedagogy and Education, 21(1), 137-152. https://doi-org.ezprimo1.idc.ac.il/10.1080/1475939X.2012.659888

Maurice, J. E., \& Harriett, A. (Ed.). (2006). The Educator's Guide to Emotional Intelligence and Academic Achievement Social-Emotional Learning in the Classroom. Saga Corwinpress, California.

Mayer, R. E. (Ed.) (2014). Cambridge handbook of multimedia learning, 2nd edition. New York, NY: Cambridge University Press. https://doi-org.ezprimo1.idc.ac.il/10.1007/978-1-4614-3185-5_31

Mesch, G. S., \& Talmud, I. (2011). Ethnic differences in Internet access: The role of occupation and exposure.

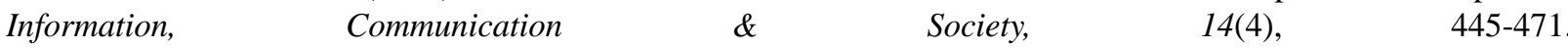
https://doi-org.ezprimo1.idc.ac.il/10.1080/1369118X.2011.562218

Meinrath, S. D., Losey, J., \& Lennett, B. (2011). A growing digital divide: Internet freedom and the negative impact of command-and-control networking. IEEE Internet Computing, 15(4), 75-79. https://doi.org/10.1109/MIC.2011.85

Moore, M. G. (1993). Theory of transactional distance. In D. Keegan (Ed.), Theoretical principles of distance education (pp. 22-38). London, New York: Routledge.

Nooreiny, M. (2007). Telling his or her story through reflective journals. International Education Journal, 8(1), 205-220.

OECD. (2018). The future of Education and skills. Education 2030. Paris:OECD Publishing.

OECD. (2019a). TALIS 2018 Results (Volume I): Teachers and school leaders as lifelong learners, TALIS. Paris: OECD Publishing.

OECD. (2019b). Trends shaping educating 2019. Paris:OECD Publishing.

Pintrich, P., Smith, D., Garcia, T., \& McKeachie, W. (1991). A manual for the use of the motivated strategies for learning questionnaire (MSLQ). National Center for Research to Improve Post secondary Teaching and Learning.

Pittman, L. D., \& Richmond, A. (2008). University belonging, friendship quality, and psychological adjustment during the transition to college. The Journal of Experimental Education, 76(4), 343-361. https://doi.org/10.3200/JEXE.76.4.343-362

Pope, C., \& Mays, N. (2009). Critical reflections on the rise of qualitative research. BMJ, 339, b3425. https://doi.org/10.1136/bmj.b3425

Rahayu, D. (2020). Synchronous zoom web conference system: An exploratory study on students' E-Learning experience. Journal of ELT Research: The Academic Journal of Studies in English Language Teaching and Learning, 5(1), 68-79.

Ramsetty, A., \& Adams, C. (2020). Impact of the digital divide in the age of COVID-19. Journal of the American Medical Informatics Association, 27(7), 1147-1148. https://doi.org/10.1093/jamia/ocaa078

Reeves, J. R. (2006). Secondary teacher attitudes toward including English-language learners in mainstream classrooms. Journal of Educational Research, 99(3), 131-143. https://doi-org.ezprimo1.idc.ac.il/10.3200/JOER.99.3.131-143

Resta, P., \& Laferrière, T. (2015). Digital equity and intercultural education. Education Information Technology, 20 , 743-756. https://doi-org.ezprimo1.idc.ac.il/10.1007/s10639-015-9419-z

Riva, G., Mantovani, F., \& Wiederhold, K. B. (2020). Positive Technology and COVID-19. Cyberpsychology, Behavior, and Social Networking, 23(9), 581-587. https://www.liebertpub.com/doi/full/10.1089/cyber.2020.29194.gri

Sahlberg, P. (2010). Rethinking accountability in a knowledge society. Journal of Educational Change, 11(1), 45-61. https://doi.org/10.1007/s10833-008-9098-2

Schneider, M., \& Preckel, F. (2017). Variables associated with achievement in higher education: A systematic review of meta-analyses. Psychological Bulletin, (143), 565-600. https://doi-org.ezprimo1.idc.ac.il/10.1037/bul0000098

Scott, J. (2016).The Politics of Market Based Education Reform. In Learning from the Federal Marketbased Reforms, edited by M. Matthis and T. Trujillo. 9-37. Charlotte, NC: Information Age Publishing. https://doi-org.ezprimo1.idc.ac.il/10.3102/0091732X16681001

Schunk, D. H. (1989). Self-efficacy and cognitive skill learning. Research on motivation in education, 3, 13-44.

Spencer, L., Ritchie, J., Lewis, J., \& Dillon, L. (2003). Quality in qualitative evaluation: A framework for assessing research evidence. London: The Cabinet Office.

Sylvester, A., Toland, J., \& Parore, P. (2017). Is the digital divide still relevant in 2017? Two cases from marginalised 
communities in Aotearoa-New Zealand. In: PACIS 2017 Proceedings, 123. Available at: http://aisel.aisnet.org/pacis2017/123

Talukdar, D., \& Gauri, D. K. (2011). Home Internet Access and Usage in the USA: Trends in the Socio-Economic Digital Divide. Communications of the Association for Information Systems, $28,7$. https://doi.org/10.17705/1CAIS.02807

Tracy, S. J. (2019). Qualitative research methods: Collecting evidence, crafting analysis, communicating impact. John Wiley \& Sons.

United Nation. (2020). Policy Brief: Education during COVID-19 and beyond. Retrieved December 2020 from: from:https://www.un.org/development/desa/dspd/wpcontent/uploads/sites/22/2020/08/

sg_policy_brief_covid-19_and_education_august_2020.pdf

Velasquez, A., Graham, C. R., \& Osguthorpe, R. (2013). Caring in a technology-mediated online high school context. Distance Education, 34(1), 97-118. doi:10.1080/01587919.2013.770435

Voogt, J., \& Pelgrum, H. (2005). ICT and curriculum change. Human Technology: An Interdisciplinary Journal on Humans in ICT Environments, 1, 157-175. https://doi.org/10.17011/ht/urn.2005356

Wareham, J., Levy, A., \& Shi, W. (2004). Wireless diffusion and mobile computing: implications for the digital divide. Telecommunications Policy, 28(5-6), 439-457. https://doi.org/10.1016/j.telpol.2003.11.005

Wiederhold, K. B. (2020). Connecting Through Technology During the COVID-19virus Disease 2019 Pandemic: Avoiding "Zoom Fatigue". Cyberpsychology, Behavior, and Social Networking, 23(7). https://www.liebertpub.com/doi/full/10.1089/cyber.2020.29188.bkw

Zilka, C. G. (2016). Reducing the digital divide among children who received desktop or hybrid computers for the home. Journal of Information Technology Education: Research, 15, 233-251. https://doi.org/10.28945/3519

Zilka, C. G. (2017a). Awareness of eSafety and potential online dangers amongst children and teenagers. Journal of Information Technology Education: Research, 16, 319-338. https://doi.org/10.28945/3864

Zilka, C. G. (2017b). Awareness of ICT capabilities, digital literacy, and use of reflective processes in children who received their first home computer. Journal of Technology Enhanced Learning, 9(1), 80-98. https://doi.org.ezprimo1.idc.ac.il/10.1504/IJTEL.2017.084074

Zilka, C. G. (2019a). The digital divide: Implications for children and adolescents' eSafety. International Journal of Technology Enhanced Learning, 11(1), 20-35. https://doi.org/10.1504/IJTEL.2019.096736

Zilka, C. G. (2019b). The use of mobile technologies by immigrant adolescents in coping with the new language and with their formal studies. In A. Forkosh-Baruch, \& H. Meishar-Tal. (Eds.). Mobile technologies in educational organizations, (pp. 192-210). IGI Global, USA.

Zilka, C. G. (2020a). Openness and development or self-criticism of preservice teachers watching videos of themselves teaching a lesson. Review of European Studies, 12(4). https://doi.org/10.5539/res.v12n4p1

Zilka, C. G. (2020b). Teenagers connected to digital environments - what happens when they get to school? Commonalities, similarities and differences from their perspective. Education and Information Technologies, 25, 1743-1758. https://doi.org/10.1007/s10639-019-10052-y

Zilka, C. G., Cohen, R., \& Rahimi, D. I. (2018). Teacher Presence and Social Presence in Virtual and Blended Courses. Journal of Information Technology Education: Research, 17, 103-126. https://doi.org/10.28945/4061

Zilka, C. G., Rahimi, D. I., \& Cohen, R. (2019). Sense of challenge, threat, self-efficacy, and motivation of students learning in virtual and blended courses. American Journal of Distance Education, 33(1), 2-15. https://doi.org/10.1080/08923647.2019.1554990

Zohar, A., \& Levy, S. T. (2019). Attraction vs. Repulsion - learning about forces and energy in chemical bonding with the Eli- Chem simulation. Chemistry Education Research and Practice, 20(4). https://doi.org/10.1039/C9RP00007K

\section{Copyrights}

Copyright for this article is retained by the author(s), with first publication rights granted to the journal.

This is an open-access article distributed under the terms and conditions of the Creative Commons Attribution license (http://creativecommons.org/licenses/by/4.0/). 